\title{
Cerebral palsy: the meaning of physical therapy for mother caregivers
}

\author{
Paralisia cerebral: o significado da fisioterapia \\ na visão de mães cuidadoras
}

\author{
Ana Carolina Pereira Domenech, Keila Okuda Tavares, Aneline Maria Ruedell, \\ Joseane Rodrigues da Silva Nobre*
}

Universidade Estadual do Oeste do Paraná (UNIOESTE), Cascavel, PR, Brazil

\begin{abstract}
Introduction: : Exercise therapy, as applied by a physiotherapist, aims to improve the acquisition of functional skills by children with cerebral palsy (CP). Treatment instructions are given to mothers, but are frequently not followed. Objective: To get to know the meaning of the role of physiotherapy in the treatment of children with CP, according to their mothers' perception; and to check mothers' compliance with physiotherapists' recommendations at home. Methods: This was a qualitative study. Interviews were conducted with 11 mother caregivers. Data were collected through interviews based on a guide questions about the meaning of the role of physiotherapy in the treatment of children with $\mathrm{CP}$, and about the continuity of care outside the outpatient setting. All the interviews were recorded, transcribed and analyzed using Bardin's content analysis technique. Results: These women have a positive perception of the physical therapy treatment; they value and recognize the benefits, by emphasizing that it provides for the physical, psychological and social recovery of their children. Mothers are aware of the benefits of treatment and that it is important to continue treatment at home. They show themselves willing and able to implement the recommendations given by the physical therapist, and demonstrate their constant concern for the welfare of their children. Conclusion: Physiotherapists should work more intensively with mothers who fail to adhere to home treatment programs. They should try and
\end{abstract}

\footnotetext{
*ACPD: BS, e-mail: anacarolinapdomenech@hotmail.com

KOT: MS, e-mail: keilaokudatavares@gmail.com

AMR: MS, e-mail: aneruedell@yahoo.com.br

JRSN: PhD, e-mail: joseane_rs@yahoo.com.br
} 
identify the reasons for their non-compliance, offer them guidance, advice, and assistance in order to clarify doubts and help solve difficulties faced by caregivers.

Keywords: Cerebral Palsy. Rehabilitation. Caregivers. Professional-Family Relations.

Resumo

Introdução: O fisioterapeuta busca melhorar a aquisição das habilidades funcionais da criança com paralisia cerebral. São repassadas orientações importantes sobre o tratamento para as mães, que muitas vezes não são seguidas. Objetivo: Conhecer o significado do tratamento fisioterapêutico para a recuperação de crianças com diagnóstico de paralisia cerebral, partindo do olhar de suas mães; verificar se essas mulheres cumprem as orientações fisioterapêuticas no ambiente domiciliar. Métodos: Trata-se de um estudo qualitativo descritivoexploratório. Foram realizadas entrevistas com 11 mães cuidadoras. A coleta de dados foi realizada por meio de uma entrevista semiestruturada baseada em perguntas norteadoras relacionadas ao significado da fisioterapia na vida da criança acometida sob o ponto de vista da mãe e sobre a continuidade do tratamento fora do ambiente ambulatorial. As entrevistas foram gravadas, transcritas, e analisadas com o Método da Análise do Conteúdo de Bardin. Resultados: Foi possível constatar que estas mulheres têm uma percepção positiva do tratamento fisioterapêutico na vida do filho; valorizam e reconhecem os benefícios do tratamento, enfatizando a recuperação da criança no aspecto físico, psicológico e social. Observou-se a conscientização dessas mulheres sobre o tratamento e sua continuidade domiciliar; elas se mostram disponíveis e ativas na execução das orientações passadas, demonstrando-se preocupadas em sempre oferecer auxílio em benefício do filho. Conclusão: o fisioterapeuta deve atuar de forma mais intensiva nos casos de não adesão ao tratamento domiciliar, buscando identificar a causa da não realização das atividades, orientando, aconselhando, e oferecendo suporte para sanar dúvidas e dificuldades enfrentadas por essas cuidadoras.

Palavras-chave: Paralisia Cerebral. Reabilitação. Cuidadores. Relações Profissional-Família.

\section{Introduction}

Cerebral palsy, also called non-progressive chronic infantile encephalopathy, occurs due to an injury that affects the central nervous system. It is characterized by a posture-and movement-dependent tone regulation disorder that adversely affects the normal development of the child $(1,2,3)$.

The etiology of cerebral palsy is multifactorial and is related to pre-, peri- and postnatal causes. Prenatal causes are toxic compounds/effects (medication, drugs), metabolic disorders (diabetes, malnutrition) and infections. Perinatal causes include hypoxia, intracranial hemorrhage, prematurity and low birth weight. Finally, postnatal causes encompass meningitis, cranio-encephalic trauma, encephalopathies and epileptic syndromes (4).

Cerebral palsy can interfere not only with the attainment of basic motor milestones, but also with the performance of activities of daily living, such as bathing, eating, and walking in varied environments. The problems presented by children with cerebral palsy cause them to need special care. Such care can range from basic assistance with activities of daily living to more complex health care services and is often provided by a family member, usually the mother, who most often takes the role of main caregiver $(5,6)$.

Parents have to deal with the impact of the diagnosis of cerebral palsy on their conceptions and expectations of their child during pregnancy. This recreates a new reality for the family and leads to some changes in their daily lives. The emotional reactions of these children's parents include mourning, shock, denial, acceptance and adaptation to the new reality (7). The whole family continually strives to adapt to the new situation by changing their daily activities and routines. These modifications due to the child's impairment can result in emotional stress, oscillating feelings and caregiver burden, which directly influences the way in which the mother and the family provide care at home. Because of that, the family needs to develop strategies to effectively address the circumstances surrounding the disability and its impact on family dynamics $(7,8)$. 
The treatment of children with cerebral palsy should be performed by a multidisciplinary team composed of physicians of various specialties, an occupational therapist, a speech therapist, a psychologistand a physical therapist $(2,9)$. The physical therapy treatment should take into account the child's normal developmental stages and aims to inhibit abnormal reflex activity and pathological movement patterns, improve muscle strength, flexibility and range of motion, and promote sensation and sensory stimulation, in order to reduce disability and improve the level of functionality of the child (9). Thus, the physical therapy intervention strategies for children with cerebral palsy seek to improve motor skills and functional performance, and hence promote greater independence of children with cerebral palsy $(10,11)$.

The interaction of the physical therapist with the family is necessary because their joint work makes it possible to strengthen the father-mother-child bond, promotes understanding and acceptance of the disease, and facilitates answering questions and explaining treatment goals. It also aims to educate parents about the importance of their participation in the treatment program. Raising parents' awareness of their role is essential to encourage the continuation of care at home, which, in turn, promotes the overall development of the child, providing benefits for the rehabilitation process $(9,12)$.

In this sense, the objectives of this study were: to get to know the meaning of the role of physical therapy in the treatment of children diagnosed with cerebral palsy, according to their mothers' perception; and to check mothers' compliance with physical therapists' recommendations at home.

\section{Methods}

This was a qualitative, descriptive/exploratory study. The study population consisted of mothers of children with cerebral palsy undergoing physical therapy at the Physical Rehabilitation Centre (PRC) of the State University of Western Paraná (UNIOESTE). Inclusion criteria were: children of both sexes aged five years or older who had been undergoing physical therapy at the PRC of the UNIOESTE for at least six months. Children under five years old were excluded from recruitment to ensure that only mothers of children who had been following a physical therapy program for some time and experienced the results of this type of intervention were addressed.
Mothers were contacted by telephone. During the telephone call they were provided with a brief description of the study and its requirements, and provided the opportunity to ask any questions. Interested mothers were scheduled to meet with the study team and complete data collection. All study participants read and signed consent forms prior to participation.

Data were collected from March to May 2013, using semi-structured interview based on the following guiding questions: (1) "For you, what is the meaning of the role of physical therapy in the treatment of your child?"; (2) "Are you able to comply with all the physical therapists' recommendations at home?". All interviews were recorded using a digital recorder and then fully transcribed for analysis. To complement the data from the interviews, after each interview, all obtained information and impressions were recorded as observation notes in a "field diary". Data were collected using a questionnaire with closed questions regarding: the mother's age, the child's age and sex, cerebral palsy classification according to the level of motor impairment, and amount of physical therapy time at the PRC of the UNIOESTE. Each participant was identified by the letter $\mathrm{M}$ (for mother) and numbered according to the sequence of the interviews. The transcribed texts were analyzed using Bardin's content analysis, which follows three steps: (1) pre-analysis, (2) exploration of the material and (3) processing, inference and interpretation of the results (13).

The study was approved by the Research Ethics Committee of UNIOESTE, Opinion number 258/2012.

\section{Results}

During the data collection period, 107 patients were being seen at the pediatric clinic of the PRC of UNIOESTE. Of these, $46(43 \%)$ had a diagnosis of cerebral palsy and 22 were aged five years or older. Only 11 of the 22 mothers contacted by telephone agreed to participate.

The mean age of the interviewed mothers was $35.64( \pm 15.10)$ years. With regard to the children, eight $(72.73 \%)$ were male and three $(27.27 \%)$ were female. Mean age was $6.55( \pm 1.16)$ years. Four children (36.36\%) were quadriplegic, 4 (36.36\%) were diplegic and 3 (27.27\%) were hemiplegic. The children had been undergoing physical therapy at the PRC for an average of $4.55( \pm 1.22)$ years. Next we 
present the results obtained after the analysis of the answers to the questions posed to the mother caregivers at the interviews.

The meaning of the role of physical therapy in the treatment of children diagnosed with cerebral palsy, according to their mothers' perception

The reading and analysis of the statements made by the mothers has shown that they see physical therapy as something essential to the lives and to the recovery of their children. They perceive it as being an indispensable treatment for children diagnosed with cerebral palsy.

"Look, the meaning of physical therapy is everything, simply everything, there is no way to explain it" (M1). "I believe physical therapy is of crucial importance for him, he cannot be without it" (M5).

The mothers in the study emphasized the importance of physical therapy in the recovery process of their children, stating that it contributes to the motor development of the children and helps them improve their functionality. They report that physical therapy helps to prevent complications, sequelae and disabilities.

"He started doing physical therapy when he was born, he even received it in the ICU, so I do think that physical therapy really did help him a lot, if he hadn't started doing it so early, he wouldn't have developed himself. [...] it helped him with everything, balance, to firm up his head and trunk, because a year and a half ago he was not able to keep his head up or make walking steps, with the difficulty he experienced with his hands, physical therapy has helped with everything and still helps" (M6).

"I always think that if he didn't do physical therapy one of his legs could become shorter than the other because the nerve would atrophy as far as I know; and maybe there could be a difference of three or five centimeters between one leg and the other, and then when he is an adult there is nothing else that can be done, there is no way to fix his leg" (M7).

"Physical therapy is very important because it stimulates all his nerves, all his functions so he doesn't have any problems in the future, because to this day I think what his future would be like if for some reason he could no longer do physical therapy" (M10).
The perception of the interviewees included in this study, is that physical therapy helps children with cerebral palsy acquire independence and autonomy. This in turn has beneficial results in terms of all developmental aspects of the children, both their physical and motor development, and their psychological and social development. In addition, the statements show that the study participants value physical therapy.

"The motor issue, the motor coordination of both his hands and legs, the ability to get around from place to place, the independence issue, I think that the role of physical therapy is to help him become independent, he is growing up and gradually getting better "(M5). "The main issue currently being worked on here is autonomy, physical therapy has greatly contributed to this psychological part of trying to do some activities alone, of trying to satisfy her needs alone, from taking off her shoes to everything else, she tries because she learns here that she can do it, she just have to give it a try, so this part has helped us a lot too" (M11).

"It's like, physical therapy has helped him a lot, both with walking issue and with the motor issue, and also with socialization, he was a very shy child, so during the first months, when we started coming here, he always cried a lot and wouldn't leave my lap, nowadays he goes downstairs by himself because he knows it's important for him" (M7).

Because they see the results of physical therapy on their children, mothers try and organize their schedules so that their children can attend physical therapy sessions as often as needed. They show concern for the development of their children and the prevention of permanent sequelae. For them, the non-continuation of treatment could be prejudicial for the development of motor skills.

"I am dedicated and I bring him here because I know he will improve, he will get better, yes, there may be some sequelae, but they will be much smaller than if he did nothing" (M7).

"It's like this, as far as the coordination is concerned, he is now in the phase of learning how to walk, and whenever we miss a day here we can already notice the difference in his leg, he pulls it up, complains that it hurts; so we cannot miss one single day here, otherwise we see that he is retrograding" (M1).

"I think physical therapy was a very good thing, as I already mentioned, many people don't know how to take 
advantage of it, so I don't miss a day, only in case of a major reason, I drop everything to come over here" (M2).

Mother caregivers recognize the importance of their role in continuing their children's treatment program at home and highlight the importance of following the recommendations given by the physical therapists.

"I think we have to take advantage of physical therapy, and when people need to do it, they should do it right because there is no point in coming here if you're not doing it right or doesn't follow their recommendations at home too" (M2).

"I do follow some ot the recommendations they gave me, I try and do it with her, I do whatever I can do, and we have already noticed a great improvement in her" (M4).

Mothers' compliance with the recommendations of physical therapists

The analysis of the transcribed interviews showed that some mothers do manage to follow all the recommendations given by the physical therapists. Attempting to follow recommendations at home turns out to be a very time-consuming task for caregivers. Yet, they strive to carry out these functions so that good results are achieved.

"If she advises the use of something that might help him, we try and use it so doesn't have to be without it and we follow her recommendations" (M1).

"I manage to do it, somehow I find a way to do it, I do, even those that are meant to be done at night before bed, I bathe him and everything. [...] you know, I do whatever I can do at home, there is not a day that don't do it" (M2)

"I manage to do it. I spare some time of my day and try and follow all her recommendations" (M4).

Some mothers, on the other hand, can only partially follow the recommendations given by the physical therapists. According to the statements, reasons for the non-compliance include: lack of time to carry out the exercises prescribed; insecurity and fear of not properly following the instructions and hindering the development of the child; lack of understanding of directions/recommendations; the non-cooperation of the child due to the association of the home with leisure time and not with physical therapy procedures.
"Sometimes one doesn't have the time to do everything one is asked to do, but I try and do the exercises that I know how to do at home. [...] I'm a little afraid of doing something wrong at home and jeopardizing something else. I guess some of it is due to the lack of information, I would like to learn how to do it right so that there are no problems" (M10).

"It's like this, everything that they tell me and I can understand enough to explain it right to him, I do" (M1). "Not everything, because he doesn't let me at home. He thinks that time at home is time to lay down, relax, doesn't let me stretch him or touch him, there's no way, it's pretty hard to do physical therapy at home with him, but sometimes I pull here and there. Depending on what we tell him to do, he sometimes tries and does it by himself, but because he does a lot of therapy, we go out almost every day, he doesn't want to do therapy at home, it's very complicated" (M6).

Mother of children with cerebral palsy frequently receive no help from other family members, they carry alone the responsibility of following the prescribed treatment at home. Only two of the 11 respondents reported receiving help from other family members with caretaking chores at home. In these cases, the recommendations of the physical therapists are passed on to the other family members, in order to promote the child's development and the rehabilitation process.

"I do whatever I'm asked to do for him, partly me and partly my mother, because she also takes care of him, we both do it" (M8).

We do it, I explain it to her father, when he gets home from work I tell him everything that happened here, how everything was and what I was told to do so he can do it too. [...] when we go visit her grandmother at the farm, I always tell her grandmother what has been done, what should be done, what we should stop doing for her and let her do by herself, because she used to be surrounded by people who wouldn't let her do anything by herself, she didn't even had to ask for something, we would already give it to her. Now it's different, now I tell her she should try it and then she goes and tries and succeeds" (M4).

We also found that some mother caregivers do not carry out exercises at home because they were never advised or requested to do so. These mother 
caregivers who have been deprived of information about treatment possibilities, however, stated that they were interested in receiving recommendations to assist in the development of their children.

"It's just that many won't give you recommendations because they don't want you to do it wrong, it's like the doctor told me, I can't do anything, only he and the physical therapist should do something, because I can harm him if I do it wrong" (M6).

"They never tell me to do anything at home, they have never told me to do something at home, sometimes I think it would be nice if they told me to do something that I could do at home, some kind of exercise" (M3).

\section{Discussion}

The results of this study indicate that mothers of children with cerebral palsy perceive physical therapy as something important for their children, both for their motor development, considering its rehabilitation and preventive approach, and for the development of psychological and social independence. Because they can see good results achieved with physical therapy, they are committed to therapy and do whatever it is in their power to follow the recommendations given by physical therapists and to make sure that their children attend physical therapy sessions as often as scheduled. Mothers recognize the importance of their role in the recovery of their children.

The recommendations given by the physical therapists cannot be always entirely followed due to women's role overload and the way they are advised to care for their children. Thus, physical therapists need to address mother caregivers differently based on their needs. Those mothers who were not carrying out any type of exercises at home reported that the reason for the non-performance was the lack of reccomendation by the physical therapist. Nevertheless, they showed themselves interested in receiving guidance, in order to ensure the welfare of their children.

A systematic review of the literature has shown that the motor prognosis in cerebral palsy is associated, among other factors, with the therapeutic assistance offered to the patient. The child's motor performance changes as he/she receives adequate treatment from a rehabilitation team, in which the physical therapist plays a very important role (14). A variety of physical therapy interventions are used in rehabilitation for children with cerebral palsy; the most used include kinesiotherapy, hydrotherapy, and hippotherapy (15).

Some mothers, as in this study, reported that physical therapy is essential for the rehabilitation of their children (16), because it allows them to make not only physical improvements but also improves behavior, social skills, autonomy and quality of life, which evidences the biopsychosocial aspect of this approach. Thus, physical therapists provide patients with a holistic treatment approach, not only from a physical point of view, but also addressing social, ethical and human issues (17).

An exploratory, descriptive, qualitative study conducted with mothers of children under five years of age with cerebral palsy has investigated the participation of parents in the rehabilitation of their children and their expectations regarding the treatment outcomes. The authors have found that mothers who had received several counseling sessions felt more secure about carrying out physical therapy exercises at home. This shows the importance of greater interaction between the physical therapist and the family. The physical therapist's task is to give clarifications and train the family to perform specific activities, reinforcing the importance of compliance with recommendations (9).

A study aiming to evaluate the effects of physical therapy in combination with guided home exercises has reported an improvement in functional performance and independence, the acquisition of new skills and better overall motor performance. The treatment protocol consisted of one-hour sessions, three times a week for three months. Patients performed kinesiotherapy exercises twice a week. Once a week, their parents received guidance and training in performing exercises at home (18).

These results show that physical therapy combined with home-based exercises contributes even more to the recovery of affected patients. Thus, in addition to encompassing the use of specific techniques, training should also stress the need for health education strategies and the provision of information about the diagnosis, the treatment and the prognosis. Parents of children with neurological sequelae such as cerebral palsy usually have many questions about the child's condition. Informed parents tend to participate more actively in the rehabilitation process and this impacts intervention outcomes (19). A study investigating the influence of the provision of physical therapy guidance 
to caregivers of children with cerebral palsy has found an improvement in the children's neurological development and stated that parental involvement directly contributes to changing this variable (20).

Thus, there is a need to reflect on the attention that is given to the parents, especially to the mother, because she is usually the family member who assumes the responsibilities and tasks associated with the treatment of the child with cerebral palsy (21). As evidenced in the statements made by the women interviewed for this study, in most cases it is the mother who receives the recommendations of the physical therapist and implements the treatment. The mother's presence and effective participation in treatment is very important, both in daily care and as part of the physical therapy team, in order to expose the child to a greater number of stimuli and enhance the desired treatment outcomes $(9,16)$.

Because cerebral palsy is a chronic disorder, the care demand of the affected child is permanent and for an indefinite period of time, which places a physical as well as emotional burden on the caregiver (22). Thus, it is necessary that other family members help with caretaking responsibilities. Mother caregivers should receive assistance with household chores and the provision of daily care (e.g., with the rotation of family members). Reinforcing the importance of this support and of working together is key to overcoming difficulties that may arise in the course of life and this experience $(3,23)$. Psychological problems are common in caregivers of children with cerebral palsy, regardless of the degree of functional impairment, and directly impact their quality of life $(6,24,25)$.

Some mothers do not carry out exercises at home due to the lack of guidance from their physical therapists (26), which was also observed in this study. The discredit given by some professionals makes family members feel devalued and creates negative feelings toward the support network that was supposed to provide care to their children. This compromises the rehabilitation program (3). The lack of knowledge about the importance of and how to perform the exercises at home, and the parents' difficulty in understanding the recommendations given by the health professionals are other factors that may contribute to non-compliance. Family members need to be better instructed on how to care for their children. Health professionals should listen to these people and then choose the most appropriate way to guide them by taking into account the specificities of each particular group (27).
When providing care to children with cerebral palsy, in addition to the knowledge of the rehabilitation process, physical therapists should gain an idea of the particularities experienced by each individual in their family environment. They should get to know other aspects of the child being treated, in order to provide individualized assistance to his/her caregivers, make the treatment more complete, and thus better contribute to the outcomes of individuals undergoing physical therapy (28).

By providing technical support, constant guidance and monitoring to family caregivers, health professionals will improve the quality of their care, making it more humane (17). The interaction between physical therapists and families of children with cerebral palsy is of paramount importance, because it helps overcome the difficulties associated with the child's physical limitations and create a bond of trust and assurance, providing mothers with the opportunity to share feelings, needs, doubts and concerns with others. This differentiated approach can encourage and strengthen the father-mother-child bond, enhance understanding and acceptance of the disease, and promote greater awareness of the importance of active participation of of all family members in treatment $(12,29,30)$.

Further qualitative studies on children's perception of physical therapy are suggested to complement the data of this paper. Finally, further quantitative studies are warranted to assess the impact of physical therapy techniques on the neurogical, psychological and motor performance of children with cerebral palsy.

\section{Conclusion}

The analysis of the interviews indicates that mother caregivers have a positive perception of the physical therapy treatment. They value and recognize the benefits of the treatment, by emphasizing that it provides for the physical, psychological and social recovery of their children.

Mothers are aware of the benefits of treatment to their children and that it is important to continue treatment at home. They show themselves willing and able to implement the recommendations given by the physical therapist, and demonstrate their constant concern for the welfare of their children. Physical therapists should work more intensively 
with mothers who fail to adhere to home treatment programs. They should try and identify the reasons for their non-compliance, offer them guidance, advice, and assistance in order to clarify doubts and help solve difficulties faced by caregivers.

\section{References}

1. Marinho APS, Souza MAB, Pimentel AM. Desempenho funcional de crianças com paralisia cerebral diparéticas e hemiparéticas. Rev Cienc Med Biol. 2008;7(1):57-66.

2. Rotta NT. Cerebral Palsy: new therapeutic possibilities. J Pediatr. 2002;78(supl.1):48-54.

3. Sandor ERS. Paralisia Cerebral: repercussões no contexto familiar [master's thesis]. São Carlos (Brazil): Universidade Federal de São Carlos; 2011. Portuguese.

4. Diament A, Cypel S. Neurologia infantil. São Paulo: Atheneu; 2005. p. 781-98.

5. Mancini MC, Alves ACM, Schaper C, Figueiredo EM, Sampaio RF, Coelho ZA. Gravidade da paralisia cerebral e desempenho funcional. Rev Bras Fisioter. 2004;8(3):253-60.

6. Carvalho JTM, Rodrigues NM, Silva LVC, Oliveira DA. Qualidade de vida das mães de crianças e adolescentes com paralisia cerebral. Fisioter Mov. 2010;23(3):389-97.

7. Dantas MAS, Collet N, Moura FM, Torquato IMB. Impacto do diagnóstico de Paralisia Cerebral para a família. Texto Contexto Enferm. 2010;19(2):229-37.

8. Francischetti SSR. A sobrecarga em cuidadores familiares de crianças portadoras de paralisia cerebral grave [master's thesis]. São Paulo: Universidade Presbiteriana Mackenzie; 2006. Portuguese.

9. Sari FL, Marcon SS. Participação da família no trabalho fisioterapêutico em crianças com paralisia cerebral. Rev Bras Crescimento Desenvolv Hum. 2008;18(3):229-39.

10. Antilla H, Autti-Rämö I, Souranta J, Mäkelä M, Malmivaara A. Effectiveness of physical therapy interventions for children with cerebral palsy: a systematic review. BMC Pediatr. 2008;8:14.
11. Barnekow K, Kraemer GW. The psychobiological theory of attachment: a viable frame of reference for early intervention providers. Phys Occup Ther Ped. 2009;25:4-15.

12. Mello R, Ichisato SMT, Marcon SS. Percepção da família quanto à doença e ao cuidado fisioterapêutico de pessoas com paralisia cerebral. Rev Bras Enferm. 2012;65(1):104-9.

13. Bardin L. Análise de Conteúdo. Lisboa: Editora 70; 2009. p. 121-70.

14. Rebel MF, Rodrigues FR, Araújo APQC, Corrêa CL. Prognóstico motor e perspectivas atuais na paralisia cerebral. Rev Bras Crescimento Desenvolv Hum. 2010;20(2):342-50.

15. Oliveira LB, Dantas ACLM, Paiva JC, Leite LP, Ferreira PHL, Abreu TMA. Recursos fisioterapêuticos na paralisia cerebral pediátrica. Catassuba. 2013;2(2):25-37.

16. Gração DC, Santos MGM. A percepção materna sobre a Paralisia Cerebral no cenário da orientação familiar. Fisioter Mov. 2008;21(2):107-13.

17. Silva IS, Silveira MFA. A humanização e a formação do profissional em fisioterapia. Cienc Saude Colet. 2011;16(1):1535-46.

18. Brianeze ACGS, Cunha AB, Peviani SM, Miranda VCR, Tognetti VBL, Rocha NACF, et al. Efeito de um programa de fisioterapia funcional em crianças com Paralisia Cerebral associado a orientações aos cuidadores: estudo preliminar. Fisioter Pesqui. 2009;16(1):40-5.

19. Ribeiro MFM, Barbosa MA, Porto CC. Paralisia cerebral e síndrome de Down: nível de conhecimento e informação dos pais. Cienc Saude Coletiva. 2011;16(4):2099-106.

20. Paliga CS, Costa JC. Orientações fisioterapêuticas aos cuidadores de crianças portadoras de Paralisia Cerebral. Rev Medica HSVP. 2005;17(37):21-4.

21. Neves ET, Cabral IE, Silveira A. Rede familial de crianças com necessidades especiais de saúde: implicações para a enfermagem. Rev Latino-Am Enfermagem. 2013;21(2):1-9.

22. Polita NB, Tacla MTGM. Rede e apoio social às famílias de crianças com paralisia cerebral. Esc Anna Nery. 2014;18(1):75-81. 
23. Dantas MAS, Pontes JF, Assis WD, Collet N. Facilidades e dificuldades da família no cuidado à criança com Paralisia Cerebral. Rev Gaucha Enferm. 2012;33(3):7703-80.

24. Marx C, Rodrigues EM, Rodrigues MM, Vilanova LCP. Depressão, ansiedade e sonolência diurna em cuidadores primários de crianças com paralisia cerebral. Rev Paul Pediatr. 2011;29(4):483-8.

25. Zanon MA, Batista, NA. Qualidade de vida e grau de ansiedade e depressão em cuidadores de crianças com paralisia cerebral. Rev Paul Pediatr. 2012;30(3):392-6.

26. Sena RR, Silva LK, Rates HF, Vivas KL, Queiroz CM, Barreto FO. O cotidiano da cuidadora no domicílio: desafios de um fazer solitário. Cogitare Enferm. 2006;11(2):124-32.

27. Milbrath VM, Siqueira HCH, Motta MGC, Amestoy SC. Família da criança com paralisia cerebral: percepção sobre as orientações da equipe de saúde. Texto Contexto Enferm. 2012;21(4):921-8.
28. Baltor MRR, Dupas G. Experiências de famílias de crianças com paralisia cerebral em contexto de vulnerabilidade social. Rev Latino-Am Enfermagem. 2013;21(4):1-8.

29. Sabatés AL, Borba RIH. As informações recebidas pelos pais durante a hospitalização do filho. Rev LatinoAm Enfermagem. 2005;13(6):968-73.

30. Vieira NGB, Mendes NC, Frota LMP, Frota MA. O cotidiano de mães com crianças portadoras de Paralisia Cerebral. RBPS. 2008;21(1):55-60.

Received in 08/02/2014

Recebido em 02/08/2014

Approved in 12/03/2015

Aprovado em 03/12/2015 
